\title{
Effects of saving and credit cooperative organizations in farmers' household condition in doyogena woreda kembata tembaro zone snnpr ethiopia
}

\author{
Abel Feleke ${ }^{1}$, Shukurala Chaimiso ${ }^{2}$ \\ ${ }^{1}$ Kembata Tembaro Zone Doyogena Woreda Trade and Industry Office \\ ${ }^{2}$ Gombora Woreda Livestock and Fishery Resource Development Office \\ *Correspondence: abelbekele2009@gmail.com
}

\begin{abstract}
The study was carried out in Doyogena district, Kembata Tembaro Zone of southern Ethiopia to assess the awareness of farmers on saving and credit cooperatives and examine the effect of SACCO's on household income generation. Multistage sampling procedure was used to select sample households. Structured interview questionnaires were prepared to collect brief information from the sample households by preparing interview schedule, focused group discussion and personal observation. For data analysis descriptive statistics like mean, frequency, percentages are used for quantitative data. In the study area, about 57.35\% of respondents are member of saving and credit service in the study area. The age, sex and educational status of household determine the cooperative member of saving and credit services. About $97.43 \%$ households are a member of cooperative saving and credit services in the age group of 30-65 years, whereas for age of households between 18-29 years were $2.57 \%$ in study area. About $97.43 \%$ of male household are a members saving and credit services.About $56.42 \%$ of sampled households are those who able to read and write were a member of saving and credits organization. The access to awareness (63.23\%), income generation are $>500$ ETB per months $41.23 \%$ respondents those are a member of SACCOs and $24.13 \%$ for non-members, un satisfy on adequacy and timeline less of loan and recovery rate(54.54\%),weak governance and weak financial management system arethe effects saving and credit service of cooperative organization in study area. Most the users of agricultural input $12(51.61 \%)$ are the members of SACCOs. This might be due to use credit from SACCOs. But non-members of cooperative are not using agricultural inputs as members SACCO due to lack credit. Therefore, creation of awareness for members and non-members, and cooperative leaders important for saving and credit services in the study area.
\end{abstract}

Keywords: Saving and credit cooperative organization, farmers' household.

\section{Introduction}

\subsection{Back ground of the Study}

The rise and expansions of modern saving and credit cooperative organizations (SACCOs) movement has its roots in the far-reaching economic social and political changes which took place in Europe in the late eighteenth and through the Nineteenth century especially during the industrial revolution and the liberation of peasantry from the feudalistic system. Saving and credit cooperative (SACC) is based largely on the ideas of referent found wide spread success mainly in USA and Canada since 1954 The central organization of American credit unions (COACU) has also stared a technical assistance program in some developing countries particularly Latin America and East Africa ${ }^{[13]}$. According to ${ }^{[11]}$, Savings and Credit Co-operative Societies (SACCOs), which are started locally, are more attractive to customers thus deeply entrenching themselves in the financial sectors of many countries. In fact, they have solid bases of small saving accounts constituting a stable and relatively low- cost source of funding and low administrative costs [11] SACCOs are able to advance loans at interest rates lower than those charged by other financial providers. In addition, SACCOs have the ability and opportunity to reach clients in areas that are unattractive to banks such as rural or poor areas. The core objective of SACCOs is to ensure members empowerment through mobilization of savings and disbursement of credit ${ }^{[12]}$.

Ethiopia is agricultural based countries and agricultural is dominate sector of national economy to bring about an improvement in economic development focus must be given to SACCOs to improve the capital investment of the society. One of the important instruments for this is developing an institution for rural or agricultural credit provision. Therefore it is essential to undertake the study of the organizations structure and procedure of credit implemented by rural cooperatives. The possibilities for saving programmers are influenced by the context in which people are living and the history of cooperative financing and financial opportunities

[Received 13 Aug 2018; Accepted 07 Dec 2018; Published (online) 31 Dec 2018] Publisher's Note: RCLSS stays neutral regard to jurisdictional claims published maps (c) (1) 
hence credit is the blood vessel of economic activity in general for rural development and agricultural production of the farmers in rural areas in Doyogenaworeda.

\subsection{Statement of the Problems}

There is no research conducted on assessment of the effects of saving and credit Cooperative Organizations in Farmers' Household Condition in the Case of Doyogena; Woreda Kambata Tambaro Zone. So that the most commonly mentioned problems by SACCO member are as follow, lack of knowledge on benefits of SACCO, lack of education and awareness of leaders of SACCOs, high registration fees and shares or contribution fees and etc. Because of the above mentioned problems non -members are restricting themselves from becoming members of SACCO ${ }^{[10]}$. In Doyogena woreda, SACCOs are facing the same problems as other cooperatives in the country. Because of this, most of the governmental and non-governmental organizations working in the cooperative promotion activity do not satisfy in the results obtained from the sector and also the effect of SACCO on the livelihood of the poor farmers were invisible. This study was therefore, planned to study the ways how farmers can increase their potential to improve effects of saving and credit cooperative in study area.

\subsection{Objectives of the Study 1.2.1 General Objective}

To analyze the effect of saving and credit cooperatives organizations saving and credit cooperatives on the livelihood of farmers in Doyogena woreda.

\subsubsection{Specific Objectives}

To identify credit cooperative organizations in Farmers' Household Condition in study area.

To identify access to awarenessand effect of saving and credit cooperatives on household income in study area.

\subsection{Research Questions}

What is the effect of saving and credit cooperatives Organizations in farmers' Household Condition in the study area.

How saving and credit cooperatives affect income level of poor households?

\subsection{Significances of the Study}

The significance of study is to provide information that was enable effective measure to improve the access to credit and saving for the famers, leader and policy makers on how and whenefforts are need in order to increase credit and savings. It was provide important recommendations and possible ways for improving the membership in SACCOs. Moreover, it will give base line for next researches that are interested on problems of SACCOs and the role of SACCOs on the livelihood of farmers in Doyogena woreda.

\subsection{Scope and Limitation of the Study}

\subsubsection{Scope of the Study}

These studies was general and provide relevant information particularly on theassessment of the effects of saving and Credit Cooperative Organizations in Farmers' Household Conditioning the study area. So that, farmers house hold can takes their own share accordingly in promoting its concepts in the study area. Moreover, the results of this study has been provide some insights and hence can serve as back bone for better research works and the result of these study will depend on the data which is collected only from July 2018 up to August 2018 .

\subsubsection{Limitation of the Study}

The successfulness of the study was limited because of the following limitation such as financial problems lack of unawareness of the respondents and lack of experience of the researcher in various activities due to these limitations the study was limited to selected two kebelesin Doyogena woreda.

\section{Literature Review \\ 2.1 Definition of Cooperative}

The definition of cooperative society and the principles that should governs its organization and operation have always been and still are the subject of heated debates and discussions in national and international cooperative circles in the search for the future form of cooperation. A universal definition of cooperative society is hard to find. There are three main school of thoughts in this reflect.

\subsubsection{The cooperative enterprise school}

This school of thought is not satisfied with improving the member's economic system but wants as a long term objective to eliminate the completive capitalist system and replace it by an economic system based on mutual cooperation.

\subsubsection{The cooperative common wealth school}

This school of thought is based on the definition that the cooperative society is a voluntary association of independent economic units.

\subsubsection{The socialist school of cooperative}

The socialist cooperative school, the most recent school of thought is based on the Marxist Leninists theory according to which cooperative can be an important step in socialist process (Franz 1968).According to ${ }^{[7]}$ a cooperative is an autonomous association that provides persons with their common economic, social and cultural needs and aspirations through jointly owned and democratically controlled enterprise. According to Holy dake" A cooperative society is an association for the purpose of joint saving; organizing among the weak and conducted a ways in an unselfish sprit on such terms that all who are prepared to assume the duties of membership may share on its rewards in proportion to the degree in which they make use of their association. According to $\mathrm{CR}$ fay cooperation is a form of organization where in persons voluntarily associated to gather as human beings on 
bases of equality for the promotion of the economic interest of themselves [18].

\subsection{Definition of SACCOs}

A SACCO is democratic unique member driven self-help cooperative it is owned governed and managed by its members who have the same common bound, working for the same goal Belonging to the same church labor, union living or working in the same community SACCO are democratize organizations and decisions are made in a structural democratic way members elect boards that in turn employ staff to carry out the boards day to day activities of the SACCO (WWW gdrco org/iemt what is ms-htm).

\subsection{Principles of Cooperatives}

The cooperative principles are the statement on cooperative identifies which was approved in Manchester continental congress in 1955.

ICA general Assembly in Manchester in September 1995 approved the drat including the statement of cooperative identity which includes the definition and values and principles the following are the poster of ICA on statement of cooperative identity this are:

Voluntary and open membership: Because cooperatives are voluntary organizations, membership is open to all persons able to use their services and willing to accept the responsibilities of membership, without gender, social, racial, political or religious discrimination.

Democratic member control: FMCS members have equal voting rights. It doesn't matter how much electricity a member consumes. When it comes to electing directors, each member has one vote.

Member economic participation: Members contribute equitably to the capital of their cooperative. At least part of that capital is usually the common property of the cooperative.

Autonomy and independence: Cooperatives are autonomous, self-help organizations, controlled by their members. If they enter into agreements with other organizations, including governments, or raise capital from external sources, they do so on terms that ensure democratic control by their members and maintain their cooperative autonomy.

Education, training and information: New challenges and new technologies affect your cooperative and the entire utility industry. Ensuring our continuing effectiveness can only be accomplished by providing information and training to the members and public, our employees, staff and directors.

Cooperation among cooperatives: We are "working together, working for you," on many levels. Cooperatives serve their members most effectively and strengthen the coop movement by participating in local, state, regional, national and international cooperative organizations.

Concern for community: This principle focuses on members' needs and prompts cooperatives to work for the sustainable development of their communities through policies accepted by their members.

\subsection{Benefits of Cooperatives}

Cooperative provide services when other cooperatives or companies are sometimes unwilling to do so in low density rural areas cooperatives also provide access to markets for farmer who would otherwise have been denied such access when other companies also provide to be a reliable source of supplies during a period of shortages. It provides rural residents with electricity water telephone service and insurance ${ }^{[3]}$.

Cooperatives can contribute to increased economic capacity of rural poor through various services which it delivers. To mention some, cooperatives are well-known for enhancing the capacity of farmers and insuring their access to productive assets and services ${ }^{[4]}$. Cloveralsoargues that cooperative are vital means of ensuring physical and economic access to sufficient, safe and nutritious food preferences for active and healthy life. Since women are vivacious behind securing nutritious food for their family, their participation in cooperative has fundamental implication for human capital development.

Cooperatives are also contributing towards gender equality by increasing female memberships well as by expanding opportunities for women in local economies and societies in many parts of the world. They support access to quality education and life-long learning opportunities by providing the means for financing education; supporting schools; establishing their own schools to provide quality education to both the youth and adults; and by serving as centers for lifelong learning ${ }^{[19]}$.

\subsection{Types of SACCO}

According to ${ }^{[20]}$, various types of SACCOs exist, depending on the membership profile and the products extended to the SACCO members differ accordingly. In essence, there are three broad categories of SACCOs:

Community-based SACCOs:These SACCOs can be found in urban areas or regional towns, but are most frequently encountered on village level. A variety of group and individual loans can be found, including women solidarity loans, business loans for individual members, or loans for small and micro enterprises;

Employee-basedSACCOs: These represent SACCOs where all the members are drawn from one employer and these SACCOs are generally located in urban areas or regional level. Specific salary-based loans are extended which are often guaranteed by the employer.

Agricultural SACCOs: To date these represent primarily small-scale cane growers in areas such as the rural region. Both individual farmers and farmers' associations can be clients of the SACCO. Loans are extended for various purposes, including agricultural production loans 


\section{ResearchMethodology}

\subsection{Description of the Study Area}

Doyogena woreda is one of the seventh woreda of Kambata Tembaro Zone in SNNPRS. The woreda is divided into 17 kebeles for administrative purpose. The woreda is bounded by Angacha woreda in Eastern direction, Hadiya Zone in North West direction, Kachabira woreda and partially Hadiya Zone in Northern direction. The woreda is located $171 \mathrm{~km}$ in South West of Hawassa, the capital city of the region of SNNP and $258 \mathrm{~km}$ South of Addis Ababa. Geographically, it is located between 7018'25"N-7021'49"N latitude and 37045'33"E37048'51" E longitude. The total population of the Woreda is 116,048 [5]. The total area of the woreda is $18,091.34$ hectare which comprises cultivated land (12,248.6 ha), forest land (3573 ha), grazing land (1110 ha), degraded land (435 ha), swampy land (358.33 ha), potentially cultivable land 202.4 hectare and others 162.4 hectare ${ }^{[6]}$.

The Woreda is located on the highlands, with an altitude ranging from 1900 up to 2800 meters above sea level. It has a minimum and maximum temperature of $10^{\circ} \mathrm{c}$ and $16^{\circ} \mathrm{C}$ respectively. The rainfall pattern is quite favorable for agriculture; with a bi-modal distribution and an annual rainfall around $1800 \mathrm{~mm}$. mixed agriculture (animal breeding and crop cultivation) is the major economic activity of the farming communities of Doyogena. Major crops cultivated in the areas are Ensete, potato, cabbage, barley, wheat, bean and pea. Next to Ensete, potato is the most important staple food crop for the farmers, and the major annual food crop traditionally cultivated during the Belg season ${ }^{[9]}$.

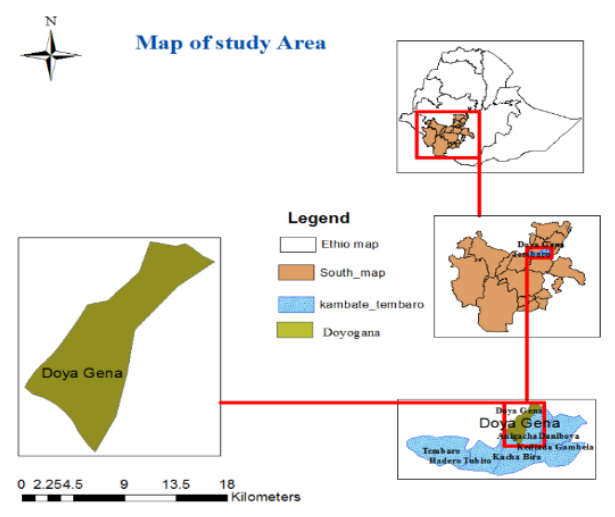

\subsection{Sampling Techniques and Sample size}

Multistage sampling procedure was used to select sample households. In the first stage, Kambata Tambar ozonewas selected purposively and secondly, Doyogena woreda was selectedpurposively.Then at the third stage, two Kebele administrative namely: Amacho and Dinikawere selected purposively out of 17 kebele two kebeles selected by considering proximity. Afterwards the sample size of the study area was determined by using Slovin's sample size determination formula at fourth stage. Accordingly from two kebele 68 respondents was selected from the total of 710 respondents in the study area. Then at fourth stage, probability to proportional size (PPS) was used to determine the proportional sample size from the two representatives Kebeles. Finally, by using the sampling frame collected from the respective Kebele administrations the $\mathrm{n}^{\text {th }}$ term of the sample is calculated by dividing the respective total households with the determined samples.

Here, by using Slovene's formulan $=\frac{\mathrm{N}}{1+\mathrm{N}(\mathrm{e})^{2}}=\frac{82}{1+82(0.05)^{2}}$ $=68$

$\mathrm{N}=$ Number of target population $=$ sample size,$\quad e=$ margin of error, its value is $10 \%$.

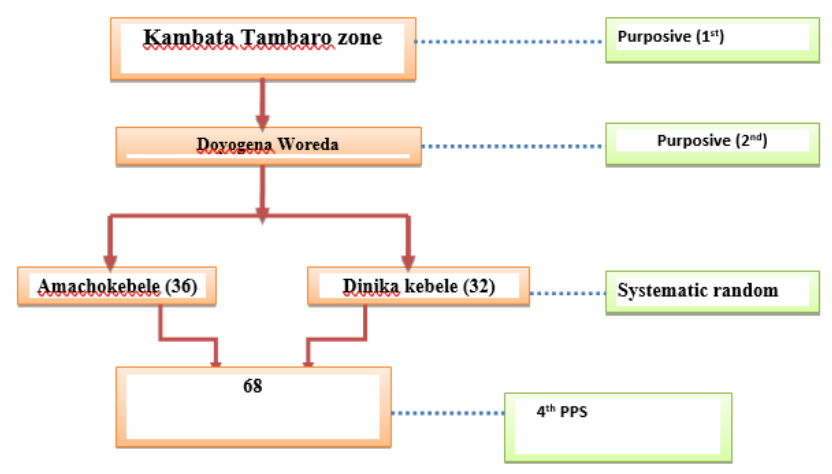

Figure 2. Sampling technique

\section{3 . Types and Source of Data}

Both qualitative and quantitative data were collected from primary and secondary sources to analyze the role of cooperatives in agricultural production and marketing. Quantitative data wascollected through interview schedules and qualitative data was collected FGD and personal observation.

\subsection{Method of Data Collection}

Data were collected from sample respondent after preparing questioners, and interview schedule, focused group discussion and personal observation.

\subsection{Methods of Data Analysis}

The collected data was analyzed by software package analyze for social science (SPSS, Version 20). The descriptive statistics like mean, frequency and percentages were analyze for quantitative data while concept explanation and elaborating description of the ideas and opinion of the informal respondents for qualitative data.

\section{Resultand Discussion}

\subsection{Socio economic Characteristics of Respondents}

The socio economic characteristics of households in study area were shown in table 1 . The study indicated that about $57.35 \%$ of respondents are member of saving and credit service in the study area. The age of household determine the cooperative member of saving and credit services.About $97.43 \%$ households are a member of cooperative saving and 
credit services in the age group of 30-65 years, whereas for age of households between 18-29 years were $2.57 \%$ in study area. In this study it was assumed that as age increases farmers would acquire knowledge and experience through continuous learning and the level of responsibility to manage the family and the need to accumulate assets for futures.

About $97.43 \%$ of male household are a members saving and credit services. It is assumed that male household heads have more exposure and access to information and new interventions than female household heads, which might enable them to participate in the saving and credit cooperative organization. importance of saving and credit, service of saving and credit, about organization of saving and credit, and implementation of saving and credit cooperative organization but $39(57.35 \%)$ of respondents are a member of saving and credit service.About 36.76 percent of the respondents were not aware about savings and credit cooperatives. Therefore, lack awareness and perception of high iterance fees are the major causes hindering member ship in SACCO due to absence trained in the study area.

The household perception on saving and credit cooperatives change the livelihood and evaluation training were shown in table 3.About $39(57.35 \%)$ and $4(5.88 \%)$ of respondents were

Table 1: Demographic characteristics of the households

\begin{tabular}{lllllll}
\hline Demographic characteristics & \multicolumn{2}{l}{ Cooperative members } & \multicolumn{2}{l}{ Non-Cooperative member } & Total \\
& $\mathrm{N}$ & percentages & $\mathrm{N}$ & Percentages & $\mathrm{N}$ & percentages \\
\hline Age of households & 1 & 2.57 & 0 & 0 & 1 & 1.47 \\
$\quad \begin{array}{l}\text { 18-29 } \\
\text { 30-65 }\end{array}$ & 38 & 97.43 & 29 & 100 & 67 & 98.53 \\
$>65$ & 0 & 0.00 & 0 & 0 & 0 & 0 \\
$\quad$ Total & 39 & 100 & 29 & 100 & 68 & 100 \\
Sex of Households & & & & & \\
$\quad$ Male & 38 & 97.43 & 21 & 72.41 & 59 & 86.80 \\
$\quad$ Female & 1 & 2.57 & 8 & 27.59 & 9 & 13.20 \\
$\quad$ Total & 39 & 100 & 29 & 100 & 68 & 100.0 \\
Educational status of household & & & & & \\
$\quad$ Illiterate & 17 & 43.58 & 27 & 93.10 & 44 & 64.70 \\
$\quad$ Read and write & 22 & 56.42 & 2 & 6.90 & 24 & 35.30 \\
$\quad$ Primary school(1-8) & 0 & 0.00 & 0 & 0.00 & 0 & 0.0 \\
$\quad$ Secondary school \& above & 0 & 0.00 & 0 & 0.00 & 0 & 0.0 \\
$\quad$ Total & 39 & 100.0 & 29 & 100 & 68 & 100.00 \\
Marital status of households & & & & & & \\
$\quad$ Married & 34 & 89.74 & 19 & 65.51 & 53 & 77.90 \\
Divorced & 0 & 0.00 & 1 & 3.44 & 1 & 1.50 \\
$\quad$ Widower & 5 & 10.26 & 9 & 31.05 & 14 & 20.60 \\
$\quad$ Total & 39 & 100 & 29 & 100 & 68 & 100.00 \\
\hline
\end{tabular}

Sample members' education status helps them not only to understand how to make money but also to prudently and profitably handle cash in financial institutions, which are found in nearby areas. The survey results revealed that $64.70 \%$ of sample household were illiterate while $35.30 \%$ were able to read and write. About $56.42 \%$ of sampled households are those who able to read and write were a member of saving and credits organization.In study area, about $77.9 \%$ of interviewed households are married. Whereas $1.5 \%$ and $20.6 \%$ are divorced and widower respectively.

\subsection{Effects of Saving and Credit Service of Cooperative} Organization

\subsubsection{Access to Awareness}

The survey results show that about $43(63.23 \%)$ of the respondents confirmed that they were trained about the recognized the importance of saving and credit cooperative to change livelihood from cooperative members and noncooperative in study area, respectively.On the contrary, $25(36.77 \%)$ of the sample household of SACCOS reported that the service were not satisfactory for change livelihood. The reason why the respondents are not satisfied by the services provide were reported in order of reasons; the committee members are weak in capacity, the resource mobilized from members is very minimal,there is bias to few members, and members of the savings and credit cooperative are very few in number.

Majority of respondents are trained and joined in cooperative members. However,almost around half of respondents are not trained. The main reason for absence of training on saving and 
credit service organization were chance given more for key informants $(44.0 \%)$, focus on cooperative members (32.0\%), unwilling to cooperative members $(12.0 \%)$, corruption when selection (8.0\%) and others in study area. This was the trained and non-trained respondents in combination emphasized that the kebele leaders and development agents play main role in the training and in selection of trainer groups.

Table3: Reason for absence of training and SACCO members

\begin{tabular}{|c|c|c|c|c|c|c|}
\hline \multirow[t]{2}{*}{ Reason } & \multicolumn{2}{|c|}{$\begin{array}{l}\text { Cooperative } \\
\text { members }\end{array}$} & \multicolumn{2}{|c|}{$\begin{array}{l}\text { Non- } \\
\text { cooperative } \\
\text { member } \\
\end{array}$} & \multicolumn{2}{|c|}{ Total } \\
\hline & $\mathrm{N}$ & $\%$ & $\mathrm{~N}$ & $\%$ & $\mathrm{~N}$ & $\%$ \\
\hline \multicolumn{7}{|l|}{$\begin{array}{l}\text { Do you think saving and credit } \\
\text { cooperatives are change } \\
\text { livelihood(yes) }\end{array}$} \\
\hline Male & 38 & 97.43 & 3 & 75.00 & 41 & 95.35 \\
\hline Female & 1 & 2.57 & 1 & 25.00 & 2 & 4.65 \\
\hline Total & 39 & 100.0 & 4 & 100.0 & 43 & 63.23 \\
\hline \multicolumn{7}{|l|}{ Absence of training } \\
\hline Unwilling of cooperative & 0 & & 3 & 12.00 & 3 & 12.00 \\
\hline $\begin{array}{l}\text { Given only for key } \\
\text { informants }\end{array}$ & 0 & & 11 & 44.00 & 11 & 44.00 \\
\hline Focusing only on members & 0 & & 8 & 32.00 & 8 & 32.00 \\
\hline $\begin{array}{l}\text { Corruption during } \\
\text { selection }\end{array}$ & 0 & & 2 & 8.00 & 2 & 8.00 \\
\hline Others & 0 & & 1 & 4.00 & 1 & 4.00 \\
\hline Total & 0 & & 25 & 100.0 & 25 & 36.77 \\
\hline
\end{tabular}

Source: Own field survey (2018)

\begin{tabular}{lllll}
\hline Variable & \multicolumn{2}{l}{$\begin{array}{l}\text { Cooperative } \\
\text { members }\end{array}$} & \multicolumn{2}{l}{$\begin{array}{l}\text { Non- } \\
\text { cooperatives }\end{array}$} \\
\hline Training & $\mathrm{N}$ & percentages & $\mathrm{N}$ & Percentages \\
\hline Trained & 39 & 100.0 & 4 & 13.79 \\
$\quad$ Non-trained & 00 & 0.00 & 25 & 86.21 \\
$\quad$ Total & 39 & 100.0 & 29 & 100.0 \\
$\begin{array}{c}\text { Training contents } \\
\text { Importance of }\end{array}$ & 17 & 43.58 & 2 & 50.0 \\
$\begin{array}{c}\text { saving and credit } \\
\quad \text { Service of }\end{array}$ & 8 & 20.51 & 1 & 25.0 \\
$\begin{array}{c}\text { saving and credit } \\
\text { Organization of }\end{array}$ & 12 & 30.76 & 1 & 25.0 \\
$\begin{array}{c}\text { saving and credit } \\
\text { Implementation of } \\
\text { saving and credit }\end{array}$ & 2 & 5.15 & 0 & 0 \\
\hline$\quad$ Total & 39 & 100.0 & 4 & 100.0 \\
\hline
\end{tabular}

\subsubsection{Income Generation of Households}

The income generation and monthly earns of the respondents in study area was shown in table 4 . The main sources of income generation of respondents are food crop production (75.86\%), off-farm income (10.34\%), cash crop production
$(6.89 \%)$ and livestock production $(6.89 \%)$ in order of importance in the study area. Both saving and credit service cooperative members and non-cooperative members have similar income generation. The most of saving and credit cooperative members get the main income from food crop production and sale $69.23 \%$ and the non-cooperative members also get their main income from food crop production and sale $75.86 \%$.

The member of saving and credit cooperative have the maximum income because mixing farming system and the saving and credit cooperative better source for income to run the agricultural production while the non-member cooperative members are poor income generating this is create a gap for sustainable agricultural production. About $58.97 \%$ saving and credit cooperative members and $75.86 \%$ noncooperatives of respondents get $<500$ ETB $38.46 \%$. This Shows that members of SACCO have the highest income due to diversified production, use of credit to fulfill their gaps in production and their soiling.

4.2.3. Adequacy and Timeliness of Loan Products and Recovery Rate by Financial Institutions

About 33 (86.84) respondents received loan from savings and credit cooperative societies. The survey results indicate that $18(54.54 \%)$ of the beneficiaries of loan disbursed by SACCOs societies were adequate and timely. On the other hand $15(45.46 \%)$ revealed that, the loan disbursed by SACCOSsocieties were inadequate and not timely.

Regarding to loan disbursed by SACCOs, the loan was not recovered on time and there were loan defaulters. Respondents who are defaulters pointed out why the reason for not repaid were reported crop failure due to natural hazards; poor follow-up of the financial institutions; the loan was beyond the capacity of borrowers; due to misuse of the loan and due to low price of agricultural commodities accordingly.

The primary benefits of those members expect after joining SACCOs. Interest on loan is the source of income for SACCOs. Income for SACCOs is expense for members. In study area, it has negative relationship with the loan size and members. This indicates that as the level of interest rate on borrowing increases it decreases the loan size and peoples did not initiated to borrow money and this declines the outreach of SACCOS in the study area. The present result was supports 
Table 4: Main sources of income and monthly earns of respondents

\begin{tabular}{lllll}
\hline Variable & \multicolumn{2}{l}{$\begin{array}{l}\text { Cooperative } \\
\text { members }\end{array}$} & \multicolumn{2}{l}{$\begin{array}{l}\text { Non-cooperative } \\
\text { members }\end{array}$} \\
\cline { 2 - 5 } & $\mathrm{N}$ & percentages & $\mathrm{N}$ & Percentages \\
\hline $\begin{array}{l}\text { Main } \\
\text { sources }\end{array}$ & & & & \\
$\begin{array}{l}\text { income } \\
\begin{array}{l}\text { Food crop } \\
\text { production } \\
\text { and sale }\end{array}\end{array}$ & 27 & 69.23 & 22 & 75.86 \\
$\begin{array}{l}\text { Cash crop } \\
\text { production } \\
\text { and sale }\end{array}$ & 5 & 12.82 & 2 & 6.89 \\
$\begin{array}{l}\text { Livestock } \\
\text { production }\end{array}$ & 3 & 7.69 & 2 & 6.89 \\
and sale & & & & \\
$\begin{array}{l}\text { Off-farm } \\
\text { income }\end{array}$ & 4 & 10.25 & 3 & 10.34 \\
$\begin{array}{l}\text { Total } \\
\text { Monthly } \\
\text { income in }\end{array}$ & 39 & 100.00 & 29 & 100.0 \\
$\begin{array}{l}\text { ETB } \\
<500\end{array}$ & 23 & 58.97 & 22 & 75.86 \\
$\quad 501-1000$ & 15 & 38.46 & 7 & 24.13 \\
$\quad 1001-$ & 1 & 2.56 & 0 & 0.00 \\
$\begin{array}{l}1500 \\
>1500\end{array}$ & 0 & 0 & 0 & 0.00 \\
\hline \multicolumn{1}{c}{ Total } & 39 & 100.0 & 29 & 100.0 \\
\hline
\end{tabular}

the findings of [2] that excessively high interest rates can attract negative publicity.

\subsubsection{Weak Governance}

Management committee members have no knowledge about financial management. In most cases SACCOs are unable to employ high caliber management staff and the burden of due diligence is left to members who may have limited education on management. The committee members elected by the general assembly to lead the affairs of the societies for fixed period do not have the necessary capacity to bring good governance, not undergone in skill upgrading. Thus, good governance is the main and crucial weakness of SACCOs.

\subsubsection{Weak Financial Management System}

The financial system in place including accounting and audit works are very weak. Most of the primary SACCOs are not maintain proper financial records and produce reports timely. Similarly, the accounts of the societies are not timely audited with three to four years lag in the case of certain primary societies. This is mainly due to limited capacity and inadequate personnel base of the regional cooperative agency and Woreda cooperative desk to provide such type of services timely as required by the cooperative proclamation. Following, SACCO are not in a position to pay dividends to members yearly unless the accounts are audited and the societies confirm profitable.

\subsection{Effect of Saving and Credit Cooperative on Food Security}

The effects of saving and credit cooperative services on food security are shown in table 5. Most the user of agricultural input $12(51.61 \%)$ are the members of SACCOs. This might be due to use credit from SACCOs. But non-members of cooperative are not using agricultural inputs as members SACCO due to lack credit. Therefore the productivity crops are low and this was cause food insecurity for the area. Food security is achieved when all people at all times have physical and economic access to sufficient, safe and nutritious food preferences for active and healthy life [4].There is strong evidence that the family farm and co-operatives can provide a decentralized system of food security and employment.

\section{Table 5: Users and purpose of credit}

\begin{tabular}{lll}
\hline Respondents & \multicolumn{2}{l}{ Cooperative members } \\
\cline { 2 - 3 } & $\mathrm{N}$ & Percentages \\
\hline Users of credit & 31 & 79.48 \\
$\quad$ Non-users of credit & 8 & 20.52 \\
$\quad$ Total & 39 & 57.35 \\
Purpose of credit & & \\
$\quad$ Buying of agricultural & 16 & 51.61 \\
inputs & & \\
$\quad$ For education & 6 & 19.35 \\
$\quad$ For food consumption & 4 & 12.90 \\
$\quad$ For health care & 3 & 9.67 \\
$\quad$ Others & 2 & 6.47 \\
\hline$\quad$ Total & 31 & 100.0 \\
\hline
\end{tabular}

Source: Own field survey (2018)

\section{Summary, Conclusion and Recommendations 5.1. Summary and conclusion}

The study was carried out in Doyogenaworeda, Kambata Tambaro Zone of southern Ethiopia to assess the awareness of farmers on saving and credit cooperatives and examine the effect of SACCO's on household income generation. Multistage sampling procedure was used to select sample households. Structured interview questionnaires were prepared to collect brief information from the sample households by preparing interview schedule, focused group discussion and personal observation. For data analysis descriptive statistics like mean, frequency, percentages are used for quantitative data.

In the study area, about $57.35 \%$ of respondents are member of saving and credit service in the study area. The age, sex and educational status of household determine the cooperative member of saving and credit services. About 97.43\% households are a member of cooperative saving and credit services in the age group of 30-65 years, whereas for age of households between $18-29$ years were $2.57 \%$ in study area. About $97.43 \%$ of male household are a members saving and 
credit services.About $56.42 \%$ of sampled households are those who able to read and write were a member of saving and credits organization.

The access to awareness $(63.23 \%)$, income generation are $>500$ ETB per months $41.23 \%$ respondents those are a member of SACCOs and $24.13 \%$ for non-members, un satisfy on adequacy and timeline less of loan and recovery rate(54.54\%),weak governance and weak financial management system arethe effects saving and credit service of cooperative organization in study area.

Most the users of agricultural input 12(51.61\%) are the members of SACCOs. This might be due to use credit from SACCOs. But non-members of cooperative are not using agricultural inputs as members SACCO due to lack credit. Therefore, from the current study it was concluded that lack awareness for members and non-members and cooperative leaders the major effects for saving and credit services in the study area.

\subsection{Recommendations}

The study revealed that a number of issues that would understand for suggestion. Awareness for members and nonmembers, and cooperative leaders are the major effects for saving and credit services in the study area.

- Creation of awareness on saving and credit services is important in study area.

- The member of saving and credit cooperatives should motivate the non-members to join SACCO.

- Promoting saving and credit services members and non-members of SACCO in the study area.

\section{References}

[1]. Bernard T., Alemayehu S. and Gabre-Madhin E. Z., 2008, 'Impact ofAgricultural Cooperatives in Ethiopia, Program Work Plan January 2004-January 2005 ,

[2]. Campion, A., Ekka, R. K., \& Wenner, M. (2010). Interest Rates and Implications for Microfinance in Latin America and the Caribbean. Working Paper Series, Inter- American Development Bank.

[3]. Chambo, S. Mwangi, Mary and Oloo, O. "An Analysis of the Socio-economic Impact of Cooperativesin Africa and Their Institutional Context, ICA Regional Office for Africa,

[4]. Clover, J. "Food Security in Sub Saharan Africa" African Security Review, Vol 12, No 1, 2003 cooperatives and poverty reduction in Africa', Working Papers on Social and Cooperativecooperatives on smallholders' commercialization behavior: evidence from Ethiopia,Agricultural Economics, 39(2), 147-161.

[5]. DWFED. (2016), Doyogena woreda finance and Economic development office
[6]. DWARD. (2012), Doyogena woreda Agriculture and Rural development office.

[7]. G.V.Veera kumran, 2004; cooperative theory and practiceEntrepreneurship, WP-SCE 08-02. Maseno University, Kenya.

[8]. Environmental Sciences, University of Minnesota, Staff Papers Series P06 January, 2006. Facilitate Access to Input and Product Markets? College of Agriculture, Food and

[9]. Getamesaye Demeke Senior Project Manager, Inter Aide - February 2014. Irish potato production in Doyogena Woreda.

[10]. Mesfin Menza, 2008. Factors affecting agricultural credit use and its impact on gross farm income of small farmers in southern Ethiopia.

[11]. Munyiri, F.N. and Ishikawa, Y., 2007. Molecular cloning and developmental expression of the gene encoding juvenile hormone esterase in the yellowspotted longicorn beetle, Psacothea Hilary's. Insect biochemistry and molecular biology, 37(5), pp.497505.

[12]. Ofei-Manu, P., Wagatsuma, T., Ishikawa, S. and Tawaraya, K., 2001. The plasma membrane strength of the root-tip cells and root phenolic compounds are correlated with Al tolerance in several common woody plants. Soil Science and Plant Nutrition, 47(2), pp.359-375.

[13]. Ortman, G. and King, R2006. "Small scale Farmers in South Africa; Can Agricultural Co-operatives.

[14]. Smith , L. Aldermen, H, Adeayoum, D. Research Report no 146,International Food Policy Research, Washington DC, 2006 submitted to USAID/ Ethiopia March 2004.

[15]. Teka G/Tekle, 2008.Members' Savings Behavior and Determinants of Savings in Rural Savings and Credit Cooperatives in Alamata and Ofla Woredas of Tigray Region, Ethiopia.

[16]. Volamen, R. "Towards Multi-Functional Global Food Systems. COGECA, Luxemburg Agricultural Council 2009.

[17]. Wanyama, F. O., Develtere, P. and Pollet, I., 2008. 'Encountering the evidence.

[18]. Y suresh Reddy A-Reddeppa Reddy 1999.

[19]. International Cooperative Alliance (ICA), 2014. Statement on the Cooperative Identity, in Review of International Cooperation, Vol. 88, No. 3.

[20]. Bwana, K.M. \& Mwakujonga, J. (2013). Issues in SACCOS Development in Kenya and Tanzania: The Historical and Development Perspectives. Developing Country Studies, 3(5), 114-121.

\section{Appendix}


This intersex schedule is prepared to collect the required dat3. Insurances

on the effect of saving and credit cooperatives on the Remittance

livelihood of farmer in you locality you are required to. Other

respond to questions in the following pages respectively. 13. 13 If No for question So 11 whey not? Because

\section{Part I.Personal related questions}

1. Age

2. Sex

1. Male 2 Female

3. Educational status

1. Can't read and write

2. Can read and write

3. Primary education

4. Secondary education ( 9 and above )

4. Marital status
1. Single
2. Married
3. Divorced

Part II. Awareness related questions

5. Have you ever trained about saving and credit cooperatives

1. Yes

$$
\text { 2. No }
$$

6. If yes more

1. On its importance

2. On its services

3. On its organization

4. On its implementation

5. Others

7. It not for No.5 why not?

1. The others of woreda cooperatives are not willing to train 4 .

2. The training only focused on the manner

3. The training is given to those who are key maturation in 8 . If No for question No 15 what measure does you taken? the kebele

4. The training groups are selected in computed manner

5. Others

8. Do you think that saving and credit cooperatives are importan to change your livelihood?

$$
\begin{array}{ll}
\text { 1. Yes } 2 \text { No } &
\end{array}
$$

9. It yes for question No 8 how it change

1. By improving the saving behavior of people

2. By giving credit

1. Saving soften

2. Participating in idir, iqub, saving and credit cooperatives

3. Waiting for aid from government

15. What is the main source of your income?

1. Food crop production and sale

2. Cash crop production and sale

4. Off farm activates

16. Do you haveany activity for generation income?
1. Yes
2.No

17. If yes for question No 15 what activity do you perform

1. Food crop production and sale

2. Cash crop production and sale

3. Lives lock production and sale

4. Off farm activities'

4. Others

19. The monthly income of your household

1. $<1000-1500$

2. $1500-2000$

3. $2000-2500$

3. By reducing the impacts of drown or by giving insurancet. $>3000$ service

4. Other

10. If not for questions no 8 why not ?Because

1. The people don't want to be mentors

2. There is no organized implementation

3. Corruptions is becoming higher

4. It targets to the rich rather than the poor

5. Other

11. Are you member of saving and credit cooperatives?
1. Yes
2. No

12. If yes for question No11, what service they provide

1. Saving

2. Provision 